\begin{tabular}{|c|c|c|}
\hline Case Reports i & \multicolumn{2}{|c|}{ Case Rep Gastroenterol 2013;7:376-380 } \\
\hline terology & $\begin{array}{l}\text { DOI: } 10.1159 / 000355165 \\
\text { Published online: September 5, } 2013\end{array}$ & $\begin{array}{l}\text { (c) } 2013 \text { S. Karger AG, Basel } \\
1662-0631 / 13 / 0073-0376 \$ 38.00 / 0 \\
\text { www.karger.com/crg }\end{array}$ \\
\hline & \multicolumn{2}{|c|}{$\begin{array}{l}\text { This is an Open Access article licensed under the terms of the Creative Common } \\
\text { Attribution-NonCommercial } 3.0 \text { Unported license (CC BY-NC) (www.karger.com/OA } \\
\text { license), applicable to the online version of the article only. Distribution permitted for non } \\
\text { commercial purposes only. }\end{array}$} \\
\hline
\end{tabular}

\title{
Biliary Cast Syndrome in an Opium Inhaler
}

\author{
Reza Dabiri Hamid Asadzadeh Aghdae Hasan Rajabalinia \\ Amir Houshang Mohammad Alizadeh \\ Shahid Beheshti University of Medical Sciences, Taleghani Hospital, Tehran, Iran
}

\section{Key Words}

Biliary cast syndrome - Endoscopic retrograde cholangiopancreatography · Opium · Biliary dyskinesia

\begin{abstract}
Biliary cast syndrome (BCS) is an uncommon complication which is mostly described in orthotopic liver transplantation. However, BCS has also been reported rarely in non-liver transplant patients. We describe a male long-term opium inhaler with BCS who underwent successful endoscopic cast removal by balloon enteroscopy-guided endoscopic retrograde cholangiopancreatography. A 52-year-old man, who was a known case of opium addiction, presented with the chief complaint of epigastric pain for 1 week prior to admission. Routine laboratory evaluation revealed cholestatic liver enzyme elevation. A cholestatic pattern was seen in radiographic modalities. Endoscopic retrograde cholangiopancreatography showed a linear filling defect in the intra- and extrahepatic duct. A long biliary cast was successfully removed using an extractor balloon. After removal of the biliary cast the patient is receiving ursodeoxycholic acid and does not report any problem 4 months after treatment. It seems that biliary dyskinesia due to long-term opium use can be a predisposing factor for biliary cast formation.

(c) 2013 S. Karger AG, Basel
\end{abstract}

\section{Introduction}

Biliary cast syndrome (BCS) is characterized by the presence of casts within the intra- or extrahepatic biliary system. Retained lithogenic material in the bile duct may lead to obstruction of the biliary tract and also to cholangitis $[1,2]$. BCS is an uncommon complication which is mostly described in orthotopic liver transplantation [1-4]. Biliary complications were reported in $6-34 \%$ of all liver transplant patients [5]. BCS is characterized by the 
Dabiri et al.: Biliary Cast Syndrome in an Opium Inhaler

presence of casts causing obstruction in the bile duct tree [1]. The exact mechanism of BCS is not well defined. Some hypotheses about cast formation in this syndrome included exudative inflammation of the bile duct epithelium [6,7], ischemic injury to the biliary endothelium [2], use of postoperative biliary drainage tubes and biliary infection [8]. BCS has also rarely been reported in non-liver transplant patients [9-14]. There is no recommended standard management for patients who develop cholangiopathy secondary to BCS, and each case should be managed individually [2].

We describe a male long-term opium inhaler with BCS who underwent successful endoscopic removal of the cast by balloon enteroscopy-guided endoscopic retrograde cholangiopancreatography.

\section{Case Report}

A 52-year-old man, who was a known case of opium addiction, presented with the chief complaint of epigastric pain for 1 week prior to admission. Physical examination showed moderate right upper quadrant tenderness. There were no significant disorders in his past medical history. Routine laboratory evaluation revealed cholestatic liver enzyme elevation with alkaline phosphatase 1,810 IU/l (reference range 80-306 IU/l), total bilirubin $0.5 \mathrm{mg} / \mathrm{dl}$ (reference range $0.1-1.2 \mathrm{mg} / \mathrm{dl}$ ) with normal aminotransferases, high erythrocyte sedimentation rate $(90 \mathrm{~mm} / \mathrm{s})$ and normal prothrombin time. Serum levels of fasting blood sugar, blood nitrogen urea, creatinine, triglyceride, total and low-density lipoprotein cholesterol and uric acid as well as thyroid function tests were in the normal range.

Ultrasound demonstrated a dilated common bile duct. An abdominal CT scan demonstrated dilated intrahepatic and extrahepatic bile ducts (the common bile duct measured $11 \mathrm{~mm}$ ). Magnetic resonance cholangiopancreatography showed a distended gallbladder and a dilated bile duct with the conclusion of ampullary and periampullary lesion (fig. 1). Endoscopic retrograde cholangiopancreatography showed a linear filling defect in the intraand extrahepatic duct (fig. 2). A long biliary cast was successfully removed using an extractor balloon (fig. 3).

The patient was discharged without any complication. After removal of the biliary cast he is receiving ursodeoxycholic acid (UDCA) $750 \mathrm{mg}$ per day and does not report any problem 4 months after treatment. His last laboratory evaluation revealed a significant decrease in erythrocyte sedimentation rate $(30 \mathrm{~mm} / \mathrm{s})$ and a mild decrease in alkaline phosphatase $(1,423 \mathrm{IU} / \mathrm{l})$.

\section{Discussion}

BCS is an obstructive cholangiopathy, defined by the presence of casts within the intraor extrahepatic biliary tract due to several mechanisms [1,2]. One study described six types for this syndrome [1]. Most of the previously reported cases of BCS were described in orthotopic liver transplantation [1-4].

Based on our knowledge and the literature, there are only five published report of BCS in a non-transplant situation [9-14]. D'Haens et al. [9] reported a case of BCS in an elderly woman after cholecystectomy. Byrne et al. [10] described BCS in a patient with traumatic head injury and prolonged intensive care unit stay. Gleeson et al. [11] described BCS in two patients, one with hepatic infarction due to antiphospholipid syndrome and the other with fasting, parenteral nutrition and infection. Katsinelos et al. [12] reported BCS in an elderly 
Dabiri et al.: Biliary Cast Syndrome in an Opium Inhaler

man after cholecystectomy. Ha et al. [13] reported two cases of BCS in non-liver surgery patients. Koo et al. [14] described a case of BCS in an elderly man after head trauma and long-term bed-ridden state. Those studies considered increased bile pigment load due to absence of gallbladder $[9,12]$, ischemic events [10-13] and gallbladder hypocontractility $[11,14]$ as the leading causes for biliary cast formation.

Structurally, in the liver transplant patients the biliary cast is composed of high bilirubin content $(10-50 \%)$, bile acids (10-15\%), few cholesterol and protein $(5-10 \%)$ or collagen from necrotic biliary epithelial cells [15]. However, the chemical composition of biliary casts in the setting of non-liver transplant patients is unclear [12].

The diagnosis is mainly based on endoscopic retrograde cholangiopancreatography or percutaneous transhepatic cholangiography [16]. There is no standard management for BCS patients, and a variety of therapeutic and surgical methods are used to treat BCS [2].

As far as we know, this is the first reported case of BCS in an opium inhaler. In our case none of the previously reported risk factors, including liver transplantation, fasting, total parenteral nutrition, hemolysis, abdominal surgery, trauma or biliary infection, was detected. In long-term opium users, bile duct size and biliary pressure were found to be larger than expected $[17,18]$. Thus, we think that biliary dyskinesia due to long-term opium use was the predisposing factor for biliary cast formation in our case.

The efficacy of UDCA use in the treatment of persistently elevated liver enzymes following endoscopic removal intervention was reported previously [12]. Our patient showed a proper therapeutic response to UDCA after cast removal too. The supposed mechanism by which UDCA acts in the treatment of BCS is dissolution of the cast in the small intrahepatic bile ducts [12], its hepatocytoprotective action and its effect on biliary acid secretion and immunomodulatory properties [19].

Generally, this case brings up the effect of opium use on BCS, and with attention to the high prevalence rate of opium consumption in Iran, this subject should be considered in these patients. Also, this case showed an effect of UDCA in the completion of treatment in BCS patients after cast removal.

\section{Conclusion}

It seems that biliary dyskinesia due to long-term opium use can be another predisposing factor for biliary cast formation, and that administration of UDCA after removal of the biliary cast is an effective treatment for BCS.

\section{References}

1 Zhu XD, Shen ZY, Chen XG, Zang YJ: Pathotyping and clinical manifestations of biliary cast syndrome in patients after an orthotopic liver transplant. Exp Clin Transplant 2013;11:142-149.

2 Srinivasaiah N, Reddy MS, Balupuri S, Talbot D, Jaques B, Manas D: Biliary cast syndrome: literature review and a single centre experience in liver transplant recipients. Hepatobiliary Pancreat Dis Int 2008;7: 300-303.

-3 Saleem A, Baron TH: Successful endoscopic treatment of biliary cast syndrome in an orthotopic liver transplant patient with a Roux-en-Y anastomosis via balloon enteroscopy. Liver Transpl 2010;16:527-529.

4 Apestegui C, Ciccarelli 0, Lerut J: Biliary cast syndrome after liver transplantation. ANZ J Surg 2012;82: 849-850.

5 Tung BY, Kimmey MB: Biliary complications of orthotopic liver transplantation. Dig Dis 1999;17:133-144.

6 Waldram R, Williams R, Calne RY: Bile composition and bile cast formation after transplantation of the liver in man. Transplantation 1975;19:382-387.

7 Zhao QC, Dou KF, He Y, Dong HL, An JZ, Kong YL, Zhang P: Histochemical and ultrastructure study of bile cast in liver transplantation patients (in Chinese). Zhonghua Wai Ke Za Zhi 2006;44:306-309. 
Dabiri et al.: Biliary Cast Syndrome in an Opium Inhaler

8 Parry D, Muiesan P: Cholangiopathy and the biliary cast syndrome. Eur J Gastroenterol Hepatol 2003;15: 341-343.

-9 D'Haens GR, Ruchim MA, Goldberg MJ, Baker AL: Massive intra-hepatic and extra-hepatic bile cast formation after cholecystectomy. Gastrointest Endosc 1993;39:579-581.

10 Byrne MF, Chong HI, O'Donovan D, Sheehan KM, Leader MB, Kay E, et al: Idiopathic cholangiopathy in a biliary cast syndrome necessitating liver transplantation following head trauma. Eur J Gastroenterol Hepatol 2003;15:415-417.

11 Gleeson FC, Czaja AJ, Baron TH: Successful endoscopic management of biliary cast syndrome in nonliver transplant patients. J Clin Gastroenterol 2008;42:752-755.

12 Katsinelos P, Kountouras J, Chatzimavroudis G, Zavos C, Pilpilidis I, Paroutoglou G: Combined endoscopic and ursodeoxycholic acid treatment of biliary cast syndrome in a non-transplant patient. World J Gastroenterol 2008;14:5223-5225.

13 Ha SI, Choi JS, Kim YH, Jun HS, Jo YG, Lee WH, et al: Biliary cast syndrome in non-liver surgery patients (in Korean). Korean J Gastroenterol 2012;60:382-385.

$\checkmark 14$ Koo JW, Jang NE, Lee HJ, Joo KR, Cha JM, Shin HP, et al: A case of biliary cast developed in a patient with long-standing biliary sludge. Clin Endosc 2013;46:98-101.

15 Shah JN, Haigh WG, Lee SP, Lucey MR, Brensinger CM, Kochman ML, et al: Biliary casts after orthotopic liver transplantation: clinical factors, treatment, biochemical analysis. Am J Gastroenterol 2003;98:1861-1867.

-16 Bak SH, Choi HS, Yang SY, Jun DW, Han SH, Lee HL, et al: Obstructive jaundice due to biliary cast syndrome followed by orthotopic liver transplantation. Korean J Gastroenterol 2006;48:119-123.

17 Thompson DR: Narcotic analgesic effects on the sphincter of Oddi: a review of the data and therapeutic implication in treating pancreatitis. Am J Gastroenterol 2001;96:1266-1272.

18 Farahmand H, PourGholami M, Fathollah MS: Chronic extrahepatic bile duct dilatation: sonographic screening in the patients with opioid addiction. Korean J Radiol 2007;8:212-215.

19 Kowdley KV: Ursodeoxycholic acid therapy in hepatobiliary disease. Am J Med 2000;108:481-486.

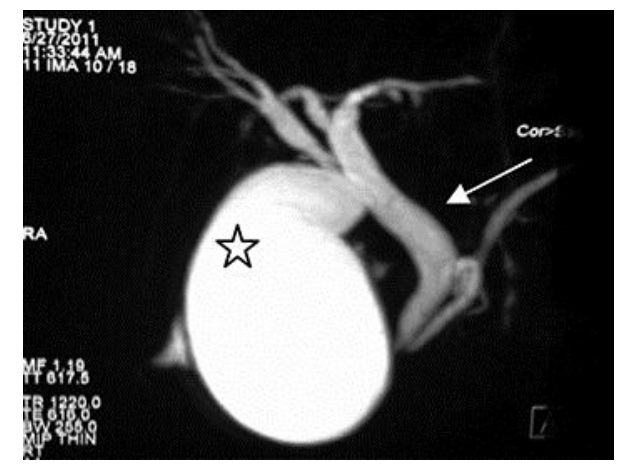

Fig. 1. Magnetic resonance cholangiopancreatography image revealing a distended gallbladder (star) and a dilated bile duct (arrow) with the conclusion of ampullary and periampullary lesion. 
Dabiri et al.: Biliary Cast Syndrome in an Opium Inhaler

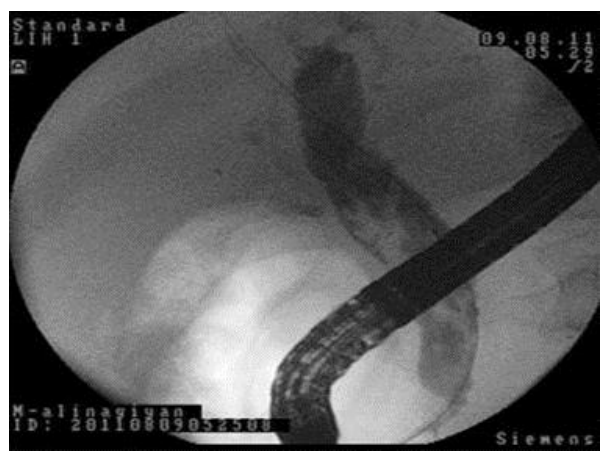

Fig. 2. Endoscopic retrograde cholangiopancreatography image revealing a linear filling defect in the intra- and extrahepatic duct.

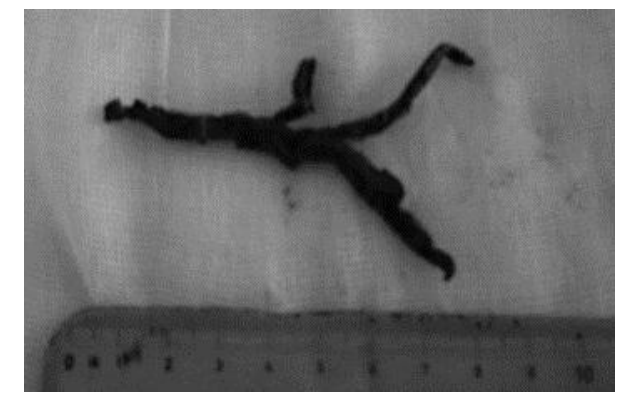

Fig. 3. The biliary cast after removal. 